OPEN ACCESS

Edited by:

Chia-Ter Chao,

National Taiwan University Hospital

Bei-Hu Branch, Taiwan

Reviewed by:

Karl Martin Wissing,

University Hospital Brussels, Belgium

Chih-Chin Kao,

Taipei Medical University

Hospital, Taiwan

*Correspondence:

Shih-Hua Lin

1521116@ndmctsgh.tw:

1521116@gmail.com

Specialty section:

This article was submitted to Nephrology

a section of the journal

Frontiers in Medicine

Received: 27 August 2021

Accepted: 20 October 2021

Published: 11 November 2021

Citation:

Chen C-C, Chen H-Y, Lu C-C and

Lin S-H (2021) Case Report:

Anti-neutrophil Cytoplasmic Antibody-Associated Vasculitis With Acute Renal Failure and Pulmonary

Hemorrhage May Occur After

COVID-19 Vaccination.

Front. Med. 8:765447.

doi: 10.3389/fmed.2021.765447

\section{Case Report: Anti-neutrophil Cytoplasmic Antibody-Associated Vasculitis With Acute Renal Failure and Pulmonary Hemorrhage May Occur After COVID-19 Vaccination}

\author{
Chien-Chou Chen ${ }^{1,2}$, Hsin-Yang Chen ${ }^{2}$, Chun-Chi Lu³ and Shih-Hua Lin ${ }^{2 *}$ \\ ${ }^{1}$ Department of Internal Medicine, Tri-service General Hospital Songshan Branch, National Defense Medical Center, Taipei, \\ Taiwan, ${ }^{2}$ Division of Nephrology, Department of Medicine, Tri-service General Hospital, National Defense Medical Center, \\ Taipei, Taiwan, ${ }^{3}$ Division of Rheumatology, Department of Medicine, Tri-service General Hospital, National Defense Medical \\ Center, Taipei, Taiwan
}

The rare and severe adverse effects associated with coronavirus disease of 2019 (COVID-19) vaccination have been under-appreciated, resulting in many instances of inappropriate management. We describe the case of an elderly woman who developed anti-neutrophil cytoplasmic antibody-associated vasculitis with pulmonary renal syndrome approximately 3 weeks after the first dose of COVID-19 mRNA vaccination (Moderna). Her nasopharyngeal polymerase chain reaction test for the COVID-19 RNA virus was negative. Gross hematuria, heavy proteinuria, acute renal failure (serum creatinine up to $6.5 \mathrm{mg} / \mathrm{dL}$ ), and hemoptysis coupled with a marked increase in serum anti-myeloperoxidase-O antibody were observed. Renal biopsy showed severe vasculitis with pauci-immune crescent glomerulonephritis. The pulmonary hemorrhage was resolved and renal function improved following combined plasma exchange and the administration of systemic steroids and anti-CD20 therapy. The early examination of urinalysis and renal function may be crucial for identifying glomerulonephritis and acute renal failure in susceptible patients after COVID-19 vaccination.

\footnotetext{
Keywords: anti-neutrophil cytoplasmic antibody (ANCA), vasculitis, vaccination, COVID-19, pulmonary renal syndrome
}

\section{INTRODUCTION}

The global pandemic caused by severe acute respiratory syndrome coronavirus 2 has led to a significant loss of life, as well as severe disruptions to economies and social activities worldwide. Coronavirus disease of 2019 (COVID-19) infection will progress to acute respiratory distress syndrome in approximately $15-30 \%$ of hospitalized patients (1). To date, over 214 million COVID-19 cases and 4 million COVID-19-related deaths have been reported globally (2). COVID-19 vaccines have been rapidly developed, and their effectiveness and safety have been demonstrated in clinical trials. The prompt implementation of mass vaccination in a large number of countries has greatly reduced COVID-19-related mortality (3). Current types of COVID-19 vaccines include the following: mRNA delivered via lipid nanoparticles, viral vectors, inactivated virus, and protein subunit vaccines (3). 


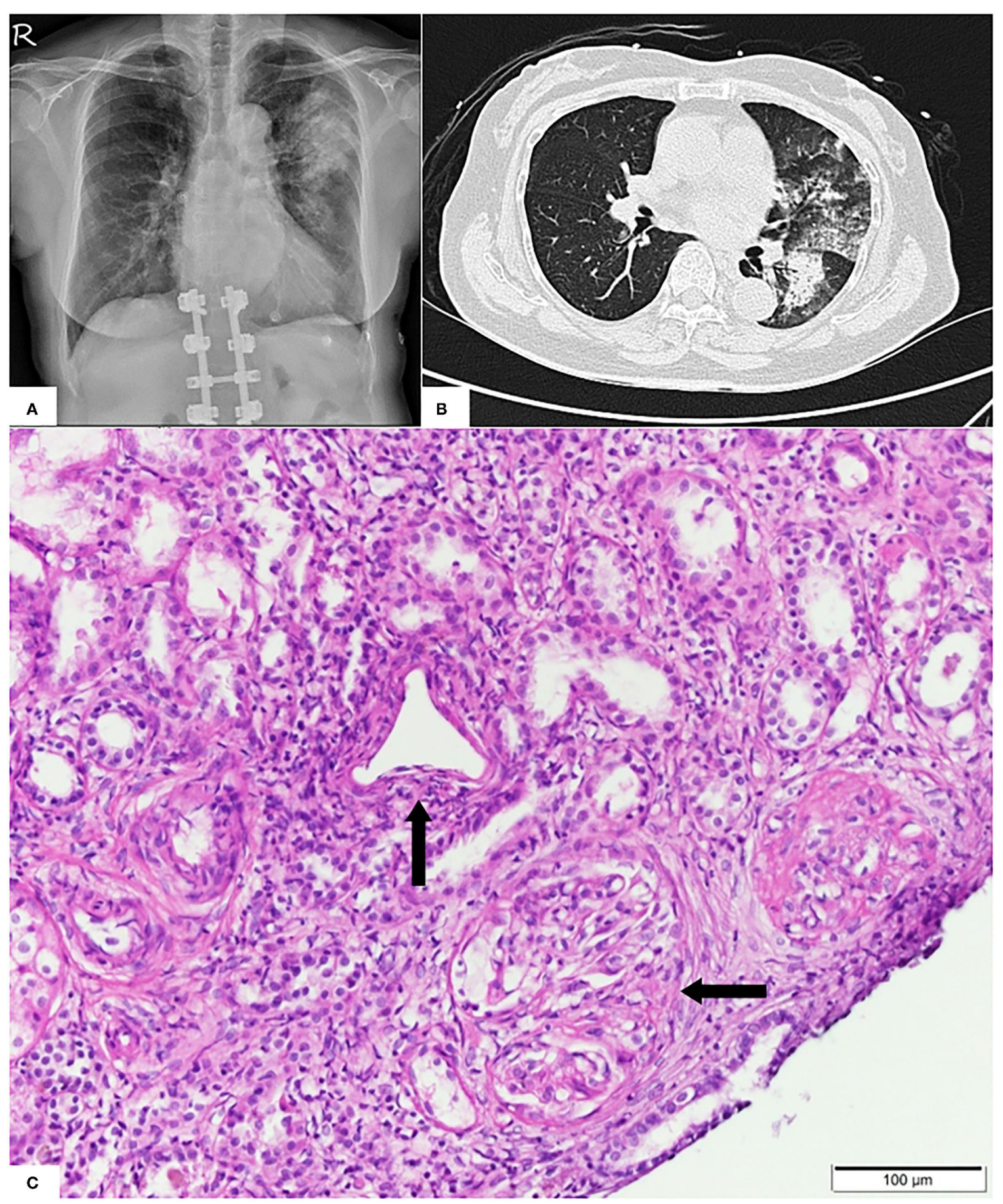

FIGURE 1 | (A) Pulmonary X-ray showing dense patchy consolidations in the left upper lung field. (B) Pulmonary computed tomography revealing peribronchial consolidations and ground glass opacities in the bilateral lung field, predominantly in the left upper lobe. (C) Light microscopy showing predominant vasculitis (parallel arrow) with pauci-immune crescent glomerulonephritis (horizontal arrow).

Due to the enhancement of the immune response by COVID-19 vaccinations, rare and serious adverse effects

Abbreviations: AAV, anti-neutrophil cytoplasmic antibody-associated vasculitis; RPGN, rapidly progressive glomerulonephritis. have been recently reported. These include vaccine-induced immune thrombotic thrombocytopenia and immune-mediated myocarditis associated with the use of viral vector vaccines and mRNA vaccines, respectively $(4,5)$. An increasing number of studies has also supported a possible link between COVID-19 


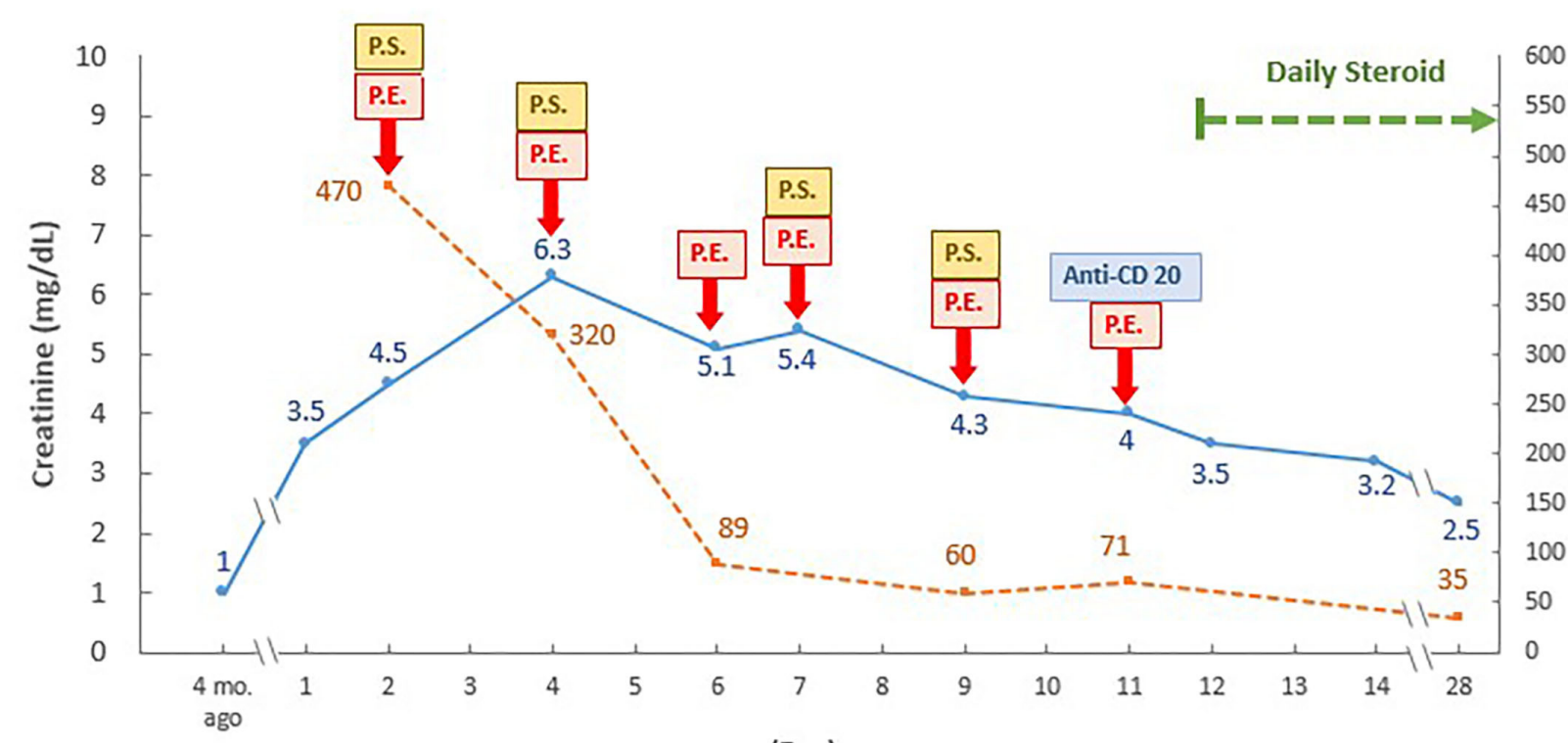

(Day)

FIGURE 2 | Time and therapeutic course of anti-neutrophil cytoplasmic antibody-associated vasculitis with rapidly progressive glomerulonephritis following COVID-19 vaccination. PE, plasma exchange; P.S., pulse steroid; ANCA, anti-neutrophil cytoplasmic antibody; Anti-MPO, anti-myeloperoxidase-O, mo., month. Daily pulse steroid dosage: intravenous methylprednisolone $1,000 \mathrm{mg}$ daily in the first course, then $500 \mathrm{mg}$ daily in the following three courses.

vaccination and the rapid development of de novo or relapsed glomerular diseases, such as anti-neutrophil cytoplasmic antibody-associated vasculitis (AAV). AAV is an autoimmune disorder characterized by small vascular inflammation, which predominantly occurs in the kidneys and in the presence of anti-neutrophil cytoplasmic antibodies and either antimyeloperoxidase or anti-proteinase 3 antibodies $(6,7)$. Here, we describe an elderly patient who developed life-threatening AAV and rapidly progressive glomerulonephritis (RPGN) and pulmonary hemorrhage 3 weeks after her first COVID-19 mRNA vaccination. The patient was successfully treated with plasma exchange and the administration of systemic steroids and anti-CD20 therapy.

\section{CASE REPORT}

A 70-year-old healthy woman was hospitalized due to worsening hematuria, proteinuria, and acute renal failure. She did not have a history of prior COVID-19 infection or medical illness (with the exception of urinary tract infection, from which she had recovered in March). The patient reported that she experienced dizziness, headache, and hematuria 1 week after the first dose of mRNA-1273 COVID-19 vaccination (Moderna); this was followed by a progressive elevation of blood pressure, gross hematuria, and decreased urine levels 2 weeks later. She was diagnosed with acute renal failure (with an incremental serum creatinine level ranging from 1.0 to 3.5 $\mathrm{mg} / \mathrm{dL}$ ) at a district hospital and were subsequently referred to medical center.
The patient was alert and oriented on admission, but developed hemoptysis and exertional dyspnea. Her supine blood pressure, heart rate, and body temperature were $160 / 90 \mathrm{mmHg}$, 88 beats/min, and $37.8^{\circ} \mathrm{C}$, respectively. Pulse oximetry indicated that her blood oxygen saturation was $96 \%$ with $28 \%$ oxygen support. The following features were noted: pale conjunctiva, shallow breathing, rhonchi, rales over the left lung field, and bilateral leg edema. The rest of her physical examination was unremarkable. Two nasopharyngeal swabs were obtained for the COVID-19 polymerase chain reaction test, both yielding negative results. Urinalysis revealed more than 100 red blood cells per high-power field and nephrotic-range proteinuria (urine protein creatinine ratio, $4,384 \mathrm{mg} / \mathrm{g}$ ). Abnormal laboratory test values included hemoglobin $(8.7 \mathrm{~g} / \mathrm{dL})$, creatinine $(3.5 \mathrm{mg} / \mathrm{dL})$, blood urea nitrogen $(88 \mathrm{mg} / \mathrm{dL})$, albumin $(3.1 \mathrm{~g} / \mathrm{dL})$, and C-reactive protein $(2.7 \mathrm{mg} / \mathrm{dL})$ levels. Arterial blood gas analysis showed $\mathrm{pH}$, partial pressure of carbon dioxide, partial pressure of oxygen, and $\mathrm{HCO}_{3}$ values of $7.45,26.1 \mathrm{mmHg}, 86.3 \mathrm{mmHg}$, and 17.5 $\mathrm{mmol} / \mathrm{L}$, respectively.

Pulmonary radiography and computed tomography showed bilateral peribronchial consolidations, which were predominantly located in the left upper lung (Figures 1A,B). Echocardiography and abdominal ultrasonography yielded normal findings. The results of immediate and thorough examinations (including immune, infection, and tumor surveys) for RPGN were unremarkable, except for a notable increase in anti-myeloperoxidase- $\mathrm{O}$ antibodies (470 IU/mL; the normal level is $<5 \mathrm{IU} / \mathrm{L}$ ). After one session of emergent plasma exchange and intravenous steroid therapy, kidney biopsy was performed 
TABLE 1 | AAV with RPGN following COVID-19 vaccination

\begin{tabular}{|c|c|c|c|c|c|c|c|c|c|c|c|c|}
\hline No & Age/Sex & Past Hx & $\begin{array}{l}\text { COVID-19 } \\
\text { vaccination }\end{array}$ & Onset & Symptoms & Urinalysis & Blood test & ANCA type & Kidney Bx & $\begin{array}{l}\text { Extra-renal } \\
\text { involvement }\end{array}$ & Treatment & Outcome \\
\hline $1^{8}$ & $52 / \mathrm{M}$ & HTN & Moderna & $\begin{array}{l}2 \text { weeks after } \\
\text { 2nd dose }\end{array}$ & $\begin{array}{l}\text { Headache } \\
\text { Weakness }\end{array}$ & $\begin{array}{l}\text { Dysmorphic } \\
\text { RBC }\end{array}$ & $\begin{array}{l}\text { SCr:8.4 } \\
\text { mg/dL, }\end{array}$ & Anti-PR3 (+) & $\begin{array}{l}\text { Pauci-immune } \\
\text { necrotizing and } \\
\text { crescentic GN }\end{array}$ & None & $\begin{array}{l}\text { Hemodialysis } \\
\text { Rituximab CYC }\end{array}$ & Dialysis-dependent \\
\hline $2^{9}$ & $81 / \mathrm{M}$ & Healthy & Moderna & $\begin{array}{l}\text { Shortly after } \\
\text { 2nd dose }\end{array}$ & $\begin{array}{l}\text { Flu-like } \\
\text { symptoms }\end{array}$ & NA & AKI & Anti-PR3 (+) & $\begin{array}{l}\text { Pauci- } \\
\text { immune crescentic } \\
\text { GN with capillary } \\
\text { necrosis \& } \\
\text { vasculitis }\end{array}$ & $\begin{array}{l}\text { Pulmonary } \\
\text { necrotic masses }\end{array}$ & $\begin{array}{l}\text { Plasma exchange } \\
\text { Pulse steroid CYC }\end{array}$ & $\begin{array}{l}\text { Improved renal } \\
\text { function }\end{array}$ \\
\hline $3^{10}$ & $77 / M$ & Healthy & AstraZeneca & $\begin{array}{l}4 \text { weeks after } \\
\text { 1st dose }\end{array}$ & $\begin{array}{l}\text { Fever, Night } \\
\text { sweating, } \\
\text { Anorexia }\end{array}$ & NA & $\begin{array}{l}\text { SCr:2.7 } \\
\text { mg/dL, CRP: } \\
20 \text { mg/dL }\end{array}$ & NA & $\begin{array}{l}\text { Non-caseating, } \\
\text { non-necrotizing } \\
\text { granuloma }\end{array}$ & None & Pulse steroid & $\begin{array}{l}\text { Resolved renal } \\
\text { function }\end{array}$ \\
\hline $4^{11}$ & $78 / \mathrm{F}$ & DM, HTN & $\begin{array}{l}\text { Pfizer- } \\
\text { BioNTech }\end{array}$ & $\begin{array}{l}\text { Immediate } \\
\text { after 2nd } \\
\text { dose }\end{array}$ & $\begin{array}{l}\text { Nausea, } \\
\text { vomiting, } \\
\text { diarrhea, } \\
\text { lethargy }\end{array}$ & $\begin{array}{l}\text { Dysmorphic } \\
\text { RBC } \\
\text { UACR:2,050 } \\
\text { mg/g }\end{array}$ & $\begin{array}{l}\text { sCr:3.5 } \\
\text { mg/dL, }\end{array}$ & Anti-MPO (+) & $\begin{array}{l}\text { Necrotizing } \\
\text { crescentic GN }\end{array}$ & None & Rituximab & $\begin{array}{l}\text { Improved } \\
\text { renal function } \\
\text { (SCr: } 1.7 \mathrm{mg} / \mathrm{dL})\end{array}$ \\
\hline $5^{12}$ & $29 / F$ & $\begin{array}{l}\text { Congenital } \\
\text { cystic lung } \\
\text { disease }\end{array}$ & $\begin{array}{l}\text { Pfizer- } \\
\text { BioNTech }\end{array}$ & $\begin{array}{l}7 \text { weeks after } \\
\text { 2nd dose }\end{array}$ & NA & $\begin{array}{l}\text { Hematuria } \\
\text { UACR:633 } \\
\mathrm{mg} / \mathrm{g}\end{array}$ & $\begin{array}{l}\text { SCr: } 1.9 \\
\text { mg/dL }\end{array}$ & $\begin{array}{l}\text { Anti-MPO (71 } \\
\text { AU/ml) }\end{array}$ & $\begin{array}{l}\text { Pauci-immune } \\
\text { crescent GN }\end{array}$ & $\begin{array}{l}\text { Chronic lung } \\
\text { infiltration }\end{array}$ & $\begin{array}{l}\text { Pulse steroid } \\
\text { Rituximab CYC }\end{array}$ & $\begin{array}{l}\text { Improved } \\
\text { renal function } \\
\text { (SCr: } 1.0 \mathrm{mg} / \mathrm{dL} \text { ) }\end{array}$ \\
\hline $6^{13}$ & $63 / M$ & Healthy & AstraZeneca & $\begin{array}{l}1 \text { week after } \\
\text { 1st dose }\end{array}$ & $\begin{array}{l}\text { Hemoptysis } \\
\text { Flu-like } \\
\text { symptoms }\end{array}$ & $\begin{array}{l}\text { Microscopic } \\
\text { hematuria }\end{array}$ & $\begin{array}{l}\text { SCr:2.9 } \\
\mathrm{mg} / \mathrm{dL}\end{array}$ & $\begin{array}{l}\text { Anti-MPO (12 } \\
\mathrm{IU} / \mathrm{ml})\end{array}$ & $\begin{array}{l}\text { Focal class of } \\
\text { pauci-immune } \\
\text { crescent GN }\end{array}$ & Infiltration over LLL & Pulse steroid & $\begin{array}{l}\text { Improved } \\
\text { renal function } \\
\text { (SCr: } 2.1 \mathrm{mg} / \mathrm{dL})\end{array}$ \\
\hline $7^{14}$ & $79 / F$ & HTN & $\begin{array}{l}\text { Pfizer- } \\
\text { BioNTech }\end{array}$ & $\begin{array}{l}2 \text { weeks after } \\
\text { 2nd dose }\end{array}$ & $\begin{array}{l}\text { Weakness } \\
\text { Upper } \\
\text { thigh pain }\end{array}$ & $\begin{array}{l}\text { Hematuria } \\
\text { UPCR: } \\
>18,000 \\
\mathrm{mg} / \mathrm{g} \\
\text { UACR < } \\
5,000 \mathrm{mg} / \mathrm{g}\end{array}$ & $\begin{array}{l}\text { SCr: } \\
6.57 \mathrm{mg} / \mathrm{dL} \\
\text { Eosinophils: } \\
23.3 \%\end{array}$ & $\begin{array}{l}\text { Anti-MPO (>134 } \\
\mathrm{IU} / \mathrm{ml})\end{array}$ & $\begin{array}{l}\text { Vasculitis with } \\
\text { pauci-immune } \\
\text { crescent GN }\end{array}$ & $\begin{array}{l}\text { CK: } 14,243 \mathrm{U} / \mathrm{L} \\
\text { Myoglobinemia } \\
>12,000 \mu \mathrm{g} / \mathrm{L}\end{array}$ & Pulse steroid CYC & $\begin{array}{l}\text { Resolved renal } \\
\text { function }\end{array}$ \\
\hline 8 & $70 / F$ & UTI & Moderna & $\begin{array}{l}3 \text { weeks after } \\
1 \text { st dose }\end{array}$ & $\begin{array}{l}\text { Headache } \\
\text { Hemoptysis } \\
\text { Hematuria }\end{array}$ & $\begin{array}{l}\text { Dysmorphic } \\
\text { RBC } \\
\text { UPCR:4,384 } \\
\text { mg/g }\end{array}$ & $\begin{array}{l}\text { SCr:3.5 } \\
\text { mg/dL } \\
\text { CRP:2.7 } \\
\text { mg/dL }\end{array}$ & $\begin{array}{l}\text { Anti-MPO (378 } \\
\text { IU/ml) }\end{array}$ & $\begin{array}{l}\text { Vasculitis with } \\
\text { pauci-immune } \\
\text { crescent GN }\end{array}$ & $\begin{array}{l}\text { Pulmonary } \\
\text { vasculitis }\end{array}$ & $\begin{array}{l}\text { Plasma exchange } \\
\text { Pulse steroid } \\
\text { Rituximab }\end{array}$ & $\begin{array}{l}\text { Improved } \\
\text { renal function } \\
\text { (SCr: } 2.5 \mathrm{mg} / \mathrm{dL} \text { ) }\end{array}$ \\
\hline
\end{tabular}

CYC, Cyclophosphamide, Hx, history, Bx, biopsy, NA, Not applicable, PR3, proteinase 3, ANCA, anti-neutrophil cytoplasmic antibody, HTN, hypertension, DM, diabetes mellitus, SCr, serum creatinine, GN, glomerulonephritis, UPCR, urine protein creatinine ratio, CKD, chronic kidney disease, CRP, C-Reactive protein, LLL, left lower lung. 
after obtaining informed consent, demonstrating acute severe renal vasculitis with pauci-immune crescent glomerulonephritis (Figure 1C).

The pulmonary hemorrhage was resolved and renal function was improved (serum creatinine, $2.5 \mathrm{mg} / \mathrm{dL}$ ) 3 weeks later, following the continuous administration of combined plasma exchange, systemic steroid, and anti-CD20 therapy (500 mg) (Figure 2). While the patient still exhibited persistent microscopic hematuria (10-75 red blood cells per high-power field), proteinuria ( $<1.0 \mathrm{~g} /$ day) was attenuated via daily steroid treatment (25 mg/day).

\section{DISCUSSION}

The patient in the present case showed typical features of AAV with RPGN and pulmonary involvement during the COVID-19 pandemic. While patients with COVID-19 infection may exhibit coexisting pneumonia and acute renal failure, thus mimicking pulmonary renal syndrome, this possibility was excluded by two negative COVID-19 polymerase chain reaction tests. As there were no other identifiable causes (e.g., other infections, malignancies, or drugs) of $\mathrm{AAV}$, the etiological factor was concluded to be the patient's first dose of the COVID-19 mRNA vaccine.

To date, eight cases (including the present report) have shown temporal links between the development of de novo AAV with RPGN and COVID-19 vaccination (Table 1). Prior cases have been mainly reported among elderly individuals without known renal diseases. Six cases have been associated with a mRNA vaccine, while a viral vector vaccine has been associated with two cases (8-14). AAV was diagnosed after either the first dose $(37.5 \%)$ or second dose $(62.5 \%)$ of COVID-19 vaccination. The onset time of symptoms varied from $<1$ week to 7 weeks (8-14). While non-specific prodromal symptoms were observed after vaccination, characteristic findings included microscopic or gross hematuria with dysmorphic red blood cells, significant proteinuria, and acute renal failure (8-14). Serum creatinine levels ranged from 1.9 to $8.4 \mathrm{mg} / \mathrm{dL}$ (8, 10-14). Extra-renal involvement with pulmonary hemorrhage, necrotic masses, consolidations and rhabdomyolysis were observed in four cases $(9,13,14)$. Although a range of different therapeutic treatments were reported, most patients exhibited improvements in renal function and pulmonary symptoms; however, one patient (serum creatinine level, 8.4 $\mathrm{mg} / \mathrm{dL}$ ) required dialysis due to irreversible renal damage (Table 1).

COVID-19 vaccination with different strategies and designs can trigger and enhance innate and adaptive immunity by activating neutrophils, $T$ cells, and $B$ cells (15). In contrast to ordinary inactivated viral or adjuvanted protein vaccines, the pioneer mRNA vaccination technique may trigger even stronger antigen-specific cluster of CD4+ and CD8+ T-cell responses and eventually exacerbate intensive immune-mediated diseases (16). Temporal AAV following COVID vaccination is reminiscent of the recently-reported AAV with immunemediated glomerulonephritis or RPGN following COVID19 infection in genetically susceptible patients, and may therefore share similar mechanisms of activation $(17,18)$. Possible mechanisms include polyclonal activation, molecular mimicry, and systemic proinflammatory cytokines response. The proinflammatory cytokines can prime neutrophils with further activation of neutrophil extracellular traps (NETs) formation and antibodies formation to myeloperoxidase and proteinase 3 $(19,20)$.

The wide-range timeline of AAV activation following COVID19 vaccination has not been elucidated. AAV with RPGN after COVID-19 vaccination could be masked by initial non-specific prodromal symptoms, making early recognition difficult. For patients with the pre-existing asymptomatic or oligosymptomatic autoimmune diseases, COVID-19 vaccination may accelerate the immune activation more rapidly, compared to other de novo immune response. Due to the limited case number, clearer timeline of immune activation post COVID-19 vaccination requires large vaccination registration studies in the future.

Given the persistent COVID-19 pandemic and the emergence of variants of concern, the rare incidence of severe adverse events after COVID-19 vaccination should not be a reason for vaccine hesitancy. Nevertheless, our patient highlighted the potential development of AAV with RPGN and pulmonary involvement following COVID-19 vaccination, suggesting that the early examination of urinalysis and renal function is imperative for the prompt recognition of glomerulonephritis and acute renal failure in vulnerable patients. The potential causal relationship between COVID-19 vaccination and the development of de novo AAV or glomerulonephritis warrants further investigation.

\section{DATA AVAILABILITY STATEMENT}

The original contributions presented in the study are included in the article/supplementary material, further inquiries can be directed to the corresponding author/s.

\section{ETHICS STATEMENT}

The studies involving human participants were reviewed and approved by Ethics Committee on Human Studies at Tri-Service General Hospital in Taiwan. The patients/participants provided their written informed consent to participate in this study. Written informed consent was obtained from the individual(s) for the publication of any potentially identifiable images or data included in this article.

\section{AUTHOR CONTRIBUTIONS}

C-CC authored the manuscript, with contribution from all authors. H-YC prepared the figure. C-CL was consulted for rheumatology problems. S-HL supervised the article. All authors contributed to the article and approved the submitted version. 


\section{REFERENCES}

1. Attaway AH, Scheraga RG, Bhimraj A, Biehl M, Hatipoglu U. Severe covid-19 pneumonia: pathogenesis and clinical management. BMJ. (2021) 372:n436. doi: 10.1136/bmj.n436

2. Johns Hopkins University Coronavirus Resource Center. COVID-19 dashboard by the Center for Systems Science and Engineering (CSSE) at Johns Hopkins University. (2021). Available online at: https://coronavirus.jhu.edu/ map.html [Accessed August 26, 2021].

3. Speiser DE, Bachmann MF. COVID-19: mechanisms of vaccination and immunity. Vaccines. (2020) 8:404. doi: 10.3390/vaccines 8030404

4. Arepally GM, Ortel TL. Vaccine-induced immune thrombotic thrombocytopenia: what we know and do not know. Blood. (2021) 138:293-98. doi: 10.1182/blood.2021012152

5. Kim HW, Jenista ER, Wendell DC, Azevedo CF, Campbell MJ, Darty SN, et al. Patients with acute myocarditis following mRNA COVID-19 vaccination. JAMA Cardiol. (2021) 21:e212828. doi: 10.1001/jamacardio.2021.2828

6. Bomback AS, Kudose S, D'Agati VD. De novo and relapsing glomerular diseases after COVID-19 vaccination: what do we know so far? Am J Kidney Dis. (2021) 6:4. doi: 10.1053/j.ajkd.2021.06.004

7. Izzedine $\mathrm{H}$, Bonilla $\mathrm{M}$, Jhaveri KD. Nephrotic syndrome and vasculitis following SARS-CoV-2 vaccine: true association or circumstantial? Nephrol Dial Transplant. (2021) 36:1565-9. doi: 10.1093/ndt/gfab215

8. Sekar A, Campbell R, Tabbara J, Rastogi P, ANCA. glomerulonephritis after the Moderna COVID-19 vaccination. Kidney Int. (2021) 100:4734. doi: 10.1016/j.kint.2021.05.017

9. Anderegg MA, Liu M, Saganas C, Montani M, Vogt B, Huynh-Do U, et al. De novo vasculitis after mRNA-1273 (Moderna) vaccination. Kidney Int. (2021) 100:474-6. doi: 10.1016/j.kint.2021.05.016

10. Gillion V, Jadoul M, Demoulin N, Aydin S, Devresse A. Granulomatous vasculitis after the AstraZeneca anti-SARS-CoV-2 vaccine. Kidney Int. (2021) 100:706-7. doi: 10.1016/j.kint.2021.06.033

11. Shakoor MT, Birkenbach MP, Lynch M. ANCA-associated vasculitis following the Pfizer-BioNTech COVID-19 vaccine. Am J Kidney Dis. (2021) 6:16. doi: 10.1053/j.ajkd.2021.06.016

12. Dube GK, Benvenuto LJ, Batal I. ANCA-associated glomerulonephritis following the Pfizer-BioNTech COVID-19 vaccine. Kidney Int Rep. (2021) 8:12. doi: 10.1016/j.ekir.2021.08.012

13. Villa M, Díaz-Crespo F, Pérez de José A, Verdalles U, Verde E, Ruiz FA, et al. A case of ANCA-associated vasculitis after AZD1222 (OxfordAstraZeneca) SARS-CoV-2 vaccination: casualty or causality? Kidney Int. (2021) 7:26. doi: 10.1016/j.kint.2021.07.026

14. Hakroush S, Tampe B. Case Report: ANCA-Associated Vasculitis Presenting With Rhabdomyolysis and Pauci-Immune Crescentic Glomerulonephritis
After Pfizer-BioNTech COVID-19 mRNA Vaccination. Front. Immunol. (2021) 12:3957. doi: 10.3389/fimmu.2021.762006

15. Teijaro JR, Farber DL. COVID-19 vaccines: modes of immune activation and future challenges. Nat Rev Immunol. (2021) 21:195-7. doi: 10.1038/s41577-021-00526-x

16. R. Talotta: Do COVID-19 RNA-based vaccines put at risk of immune-mediated diseases? In reply to "potential antigenic crossreactivity between SARS-CoV-2 and human tissue with a possible link to an increase in autoimmune diseases". Clin Immunol. (2021) 224:108665. doi: 10.1016/j.clim.2021.108665

17. Izci Duran T, Turkmen E, Dilek M, Sayarlioglu H, Arik N. ANCAassociated vasculitis after COVID-19. Rheumatol Int. (2021) 41:15239. doi: 10.1007/s00296-021-04914-3

18. Godri Pollitt KJ, Peccia J, Ko AI, Kaminski N, Dela Cruz CS, Nebert DW, et al. COVID-19 vulnerability: the potential impact of genetic susceptibility and airborne transmission. Hum Genomics. (2020) 14:17. doi: 10.1186/s40246-020-00267-3

19. Jeffs LS, Nitschke J, Tervaert JW, Peh CA, Hurtado PR. Viral RNA in the influenza vaccine may have contributed to the development of ANCA-associated vasculitis in a patient following immunisation. Clin Rheumatol. (2016) 35:943-51. doi: 10.1007/s10067-0153073-0

20. Nakazawa D, Masuda S, Tomaru U, Ishizu A. Pathogenesis and therapeutic interventions for ANCA-associated vasculitis. Nat Rev Rheumatol. (2019) 15:91-101. doi: 10.1038/s41584-0180145-y

Conflict of Interest: The authors declare that the research was conducted in the absence of any commercial or financial relationships that could be construed as a potential conflict of interest.

Publisher's Note: All claims expressed in this article are solely those of the authors and do not necessarily represent those of their affiliated organizations, or those of the publisher, the editors and the reviewers. Any product that may be evaluated in this article, or claim that may be made by its manufacturer, is not guaranteed or endorsed by the publisher.

Copyright (c) 2021 Chen, Chen, Lu and Lin. This is an open-access article distributed under the terms of the Creative Commons Attribution License (CC BY). The use, distribution or reproduction in other forums is permitted, provided the original author(s) and the copyright owner(s) are credited and that the original publication in this journal is cited, in accordance with accepted academic practice. No use, distribution or reproduction is permitted which does not comply with these terms. 